\title{
V Travel Writing and Representation: Africa in William J. Hemminger's African Son
}

\author{
By Manyaka Toko Djockoua*
}

\begin{abstract}
This article examines the relationship between travel writing and representation, a key concept in postcolonial discourse, grounded in the binary opposition self/other. It argues that unlike his Western counterparts, Hemminger, in African Son, associates Africa with enlightenment, humility and self-discovery. This land is therefore a challenge not only to the racially prejudiced Westerner but also to the African native, who approaches it with a colonialist mindset. This thus drives to the claim that African Son, not only implements a new vision of Africa- which is more realistic than that presented by some Western and African colonialists, politicians, and explorersbut it also gives a new insight into the postcolonial binary self/other. It shows that travel writing can depart from the original role assigned to it by former Western explorers and imperialists. Today, at a time when African immigrants confront racism in Western countries and some Western immigrants are kidnapped and slain by radical groups in Africa, Hemminger's book stands as a counter discourse and counter reaction to racism and otherness, and thus warns against an unbridled resurgence of nationalism and racial essentialism.
\end{abstract}

\section{Introduction}

Western migrations to Africa, motivated by territorial expansion, exploration, religion, imperialism, colonization, and tourism, have given rise to a body of travel writings that recount the travelers' real or imagined experiences in the places that they visited physically or through imagination. Most Western travelogues such as Joseph Conrad's Heart of Darkness (1899) have represented Africa as the dark continent. ${ }^{1}$ This representation has not much changed in the twentieth and twenty-first centuries. Unlike the American continent that was portrayed by the first European explorers as a land of plenty,

\footnotetext{
*Associate Professor of American Literature, University of Yaoundé 1, Cameroon.

${ }^{1}$ Amongst other Western travelogues that describe Africa as dark and backward, rank the following: Leo Africanus's Description of Africa (1550), Mungo Park's Travels into the Interior of Africa ( (1779), Henry Morton Stanley's Through the Dark Continent (1878) and In Darkest Africa (1890). See Hulme \& Youngs 2002, pp. 156-162.
} 
the world's breadbasket and Eldorado ${ }^{1}$, Africa was and still is pictured in Western travelogues as the dark continent, the land of poverty, war and famine.

This misrepresentation has brought about numerous reactions from African writers and scholars; one of the most cited is Chinua Achebe's "An Image of Africa: Racism in Conrad's 'Heart of Darkness"' (1977), a counter discourse to Conrad's text, which, to Achebe, "projects the image of Africa as "the other world," the antithesis of Europe and therefore of civilization.' Like Achebe's article, Hemminger's travelogue African Son is a counter reaction to colonialist Western travel writings, even if his book replicates some of the clichés assigned to the African continent. This article thus seeks to address the following questions: Why does African Son's representation of Africa depart from the age-old perception of this continent? What is the book's contribution to travel writing, a genre so open to changes, which is still struggling to establish itself in its own right?

Hemminger first encountered Africa as a Peace Corps volunteer. This first contact impacted on his stance vis-a vis this continent where he lived with the people whose culture he tried to understand. Even when he visited this land later as a university professor, his vision of Africa did not change much. This thus drives to the claim that African Son, a collection of fifteen stories written by a European American, implements a new image of Africa, which is more realistic than that presented by foreign and national colonialists, politicians, and explorers. This article thus purports that Hemminger espouses Linda Krumholz's contention that 'insight requires an inward vision and the ability to see the self in the other and the other in the self... The perception of the self in the other creates common ground; the perception of the other in the self creates new possibilities for self-knowledge" (African American Review 30).

To study the shift in the postcolonial self/ other binary, one needs to define travel writing and its intricate link to representation. Peter Hulme and Tim Youngs, in The Cambridge Companion to Travel Writing (2002), argue that:

travel writing is best considered as a broad and ever-shifting genre, with a complex history which has yet to be properly studied...just as the ways of travel are constantly changing, so travel writing will continue to change in their wake: stories emerging from space travel, from virtual travel, from the 'travails' of the world's refugees and migrants will doubtless continue to extend the genre in the years to come. (11)

These critics point at the changing aspect of travel writing, a genre which, though rooted in travel, borrows from many fields of study: history, geography, journalism, literature, and anthropology, to name just these. As people's

\footnotetext{
${ }^{1}$ In Agrarianism in American Literature, Inge points out that 'to the mind of the European during the age of discovery, America suggested a virgin land, an unspoiled and undefiled garden of Eden, a new Arcadia.' (INGE T., 1969, p.1).
} 
movements from one area to another vary in purpose and means of transport, so too does travel writing change in scope and objectives.

In postcolonial discourse, travel writing is associated with representation and specifically otherness, which leads to Eunyoung Oh's assertion in $D$. $H$. Lawrence's Border Crossing: Colonialism in His Travel Writings and "Leadership" Novels:

As a significant part of colonial discourse, Western travel booksparticularly adventure stories of Western imperialists-have been used to confirm the cultural and racial superiority of the West. Most critics would agree about the active involvement of travel literature with colonialist ideology. For instance, Wimal Dissanayake and Carmen Wickramagamage define Western travel writing as 'a metonym for colonial expansion.' (1)

Seeking to confirm the cultural and racial superiority of the West, Western travel writing has resorted to gross misrepresentation of other cultures and peoples, specifically peoples of African descent. The first section of this article will therefore deal with some of the old stereotypical images of Africa that resurface in Hemminger's book, while the second section will show the new picture of Africa that derives from the writer's 'ability to see the self in the other and the other in the self.'

\section{Africa and the Colonialist Ideology}

In Orientalism (1978), Edward Said shows how the Orient was constructed by European Culture (3). To paraphrase Said, one will say that Western Culture has produced Africa politically, sociologically, militarily, ideologically, scientifically, and imaginatively.

Quoting the American journalist Helen Winternitz, Youngs recaptures her statement about Zaire:

Zaire's darkness was not geographic. It was not the fruit of the entangling forest, but a creation of man. The dark legacy of the Portuguese slavers who betrayed the Mani Kongo has carried through the years of the tyrant Leopold, to Mobutu and his system grounded in torture, repression, and corruption. Those who put Mobutu in place and have kept him there have been foreigners, first among them the American policymakers, who can pretend, as the Belgians and the other Europeans did, that they have been bringing light to Africa. (Hulme \&Youngs 168) ${ }^{1}$

${ }^{1}$ See Helen Winternitz (1987), East Along the Equator: A Journey up the Congo and into Zaire. New York: The Atlantic Monthly Press, p. 263. 
This assertion is applicable to other African countries. Africa's darkness was constructed by the West to conceal the real motive of its colonization of this part of the world, rich in cheap labor and natural resources so much needed by European industries and American cotton and sugarcane plantations. To achieve their goal, European colonialists had to stage a bogus civilizing mission that they could carry out through African leaders with a colonialist mindset.

It is worth mentioning that the experiences narrated in the fifteen sketches of African Son are set in three different geographical settings, and three different periods. The first essays (chapters one, two, three, four and five) are set in the 1980s in Senegal, a country in West Africa. The second part (chapters five, six, seven, and eight), which is set in the 1990s, includes countries such as Madagascar, Zimbabwe, Malawi and Mozambique in the south-east of Africa. The third group of essays is set in 2004-2005 in Cameroon, a country in central Africa. Despite their different settings in time and space, most of the sketches represent Africa in relation to the colonialist ideology that the author deconstructs. As Richard Bradshaw points out in his comment on the book, "These vignettes of daily life in various African countries and the experiences of ex-patriots provide insights about human agency, which most textbooks fail to convey" (African Son, blurb). Like the American journalist Winternitz, Hemminger 'turns our attention away from nature to humanity', as he focuses more on human and interracial relationships.

African Son shows some of the stereotypes assigned to Africa by both the Western and African colonialists. As Tim Youngs purports:

European enslavement of Africans had been partially enabled by, and in turn reinforced, an image of black Africans as inferior and uncivilized, while the nineteenth-century movement against Arab and Portuguese slavers fostered a paternalistic feeling that Africans required European protection. Anthropological discourse in its specialized and popularized forms classified black people as humanity in its most primitive state. (Hulme \& Youngs 157)

This vision of Africa and Africans rationalizes inequities, racial discrimination and marginalization as it asserts the superiority of the white self and the inferiority of the black other in most Western travelogues. The self in the context of this article is related to any individual or group that possesses power and thus exerts domination on the powerless individual or group that it brands as other. In other words, the concept self/other correlates with the opposition colonizer/colonized built not only on race but also on class differences.

The first essay (Chapter One), "A Friend of the Family," dwells on the relationship between the narrator and Abdou Diop's family. Through a seemingly banal story of an encounter of a young Peace Corps volunteer and a native Senegalese family, the reader is called upon to ponder over corruption, otherness, racial and cultural differences, the gap between tradition and 
modernity, death, human compassion and man's exploitation by his fellow man. The author's use of binaries sheds light on the European settler's opulence and the African native worker s' destitute state. Although Abdou Diop, the head of the family is fortunate enough to work on the French sugarcane plantation, he has to depend on a 21-one year-old American Peace Corps youth for medical care and sometimes food. His backbreaking and mindnumbing job enslaves him, yet fails to provide him financial security.

The plantation on which the Duponts, the white colonialist's family, and the Diops live reveals gross inequalities between the white French boss and the black Senegalese workers. The native's slum is contrasted with the DuPont's' house, a replica of a French home in a former African colony:

The Duponts lived for a few months of the year in a compound that housed themselves and the other toubab managers of the plant. The entire ensemble of homes was surrounded by a continuous cinderblock wall topped by shards of glass that sparked eerily in the sun. The individual houses, electrified by a portable generator, were miniature tropical replicas of homes in France and England-filled with imported niceties, surrounded by pretty gardens that had to be watered twice daily.(2)

The houses described bring forth the author's use of contrast. In his statement, 'I got to see the other side,' the other side refers to the European quarter and its luxury houses that point at the difference between the rich colonialists and the poor natives. The narrator's view is not limited to one side. As he has an insight into the two social environments, the narrator exposes the flaws of the European colonialist and those of the African native.

Both groups' short-sightedness impedes their ability to see beyond their own space. The Duponts live in a world of luxury that does not enable them to really know their black employees, while the Diops' blind belief in traditional medicine - even when the latter proves inefficient in curing some diseasesmakes them victims of disasters. Iba's death and Baïdy's poor health illustrate the parents' neglect of their progeny:

Baïdy would have made a suitable candidate for the photos that came out of Sahelian Africa at that time-bloated children sitting in squalor, with may be a skeletal and leafless thorn tree nearby. Everyone at home saw those pictures, and well-meaning folks sent many dollars to relief agencies. Many of those dollars came to line the pockets of local government officials; bags of US corn were sold to villagers despite the words emblazoned on the burlap- 'gifts of the US government.' The mayor of our region got relatively rich on those gifts, this 'redistribution of wealth.' But Baïdy got no benefit from the international relief effort. (4) 
The photos on Western media picture that Africa of famine brought on by natural catastrophes such as drought. Both human beings and animals are victims of these catastrophes. Yet other evils that mar the continent are manmade. The officials who embezzle the state funds and aids from the international community render Africa a beggar, while they enrich themselves. Self-centeredness hinders the development of this continent. Baïdy's poor physical appearance fuels the author's pungent criticism of Western aids to African countries. It shows that it does not suffice to send money and other goods to poor countries. Donors should put in place mechanisms that force the governments of recipient countries to ensure the equitable distribution of the aids to their needy masses.

In Chapters three and four, the flaws of the Senegalese rulers are exposed in the government's neglect of the village people's education in Saniente where the collapse of the sole village school is unnoticed by the government (13) and in the description of Dakar as an epitome of gross inequalities and inequities. It is a town 'where western life-styles most clearly clash with African traditions' (20). Dakar embeds the same ills that plague Yaoundé in Chapter nine, 'Out of Country'. The colonialist ideology imbibed by the postcolonial African administration favors exploitation, as Joyce Sympson observes in his online comment on the book, 'Bill Hemminger has good insight into the Western world's relationship with Africa: sometimes friendly, sometimes exploitative, almost always awkward'. This exploitative relationship prevails in the interaction between the rich African 'comprador bourgeoisie' and their poor masses.

Adopting the former master's ideology, African colonialists rationalize the stereotypes replicated by Marian's parents in Chapter Seven, 'Native Speaker': 'And you couldn't possibly go over there. Think of the filth and the bugs. What would you eat? How would you live? You couldn't even speak to those people' (42). The parents, who oppose their daughter's marriage to an African, George Mutare, connect Africa to filth and famine. Their representation of this land is akin to Claude McKay's depiction of this continent in his poem 'Africa': 'The darkness swallowed thee again/ Thou art the harlot; now thy time is done/Of all the nations of the sun (Baym, 1408). If Africa's time is done, its future looks bleak. Yet the second part of this article proves that this vision of Africa is debunked in Hemminger's book.

\section{African Son as Counter Discourse}

Although the first section of this article has shown that African Son recaptures some of the stereotypical images ascribed to Africa, this book is a counter discourse to colonialist travelogues. In 'The Politics of Rewriting,' C.L. Innes posits thus:

At stake in many rewritings of canonical European texts is the question of authority and authenticity, linked to issues of 
representation and self-representation: the insider establishes the authority of his or her narrative and account of the culture over the outsider's version. (Chew \&Richards 57)

Hemminger has not rewritten Conrad's Heart of Darkness as Achebe has done, yet he has tackled the issues of representation and self-representation from an insider's perspective. In African Son, and this is where the originality of Hemminger's travel writing lies, the superiority of the white self and the inferiority of the black other are entwined, and the book thus challenges the reader to distinguish the racial and cultural center from the racial and cultural margin. It rather reiterates Wladimir Berelowitch's perception of travel, which Derek Offord exposes thus: 'Travel also afforded opportunities to appreciate natural beauty or experience aesthetic pleasure as well as to observe the manners, customs, philosophies, religions and forms of government of foreign peoples. It seemed even to enable people to discover themselves...' (Journeys to a Graveyard 3).

Hemminger's travels to Africa have enabled him to achieve all the above mentioned goals. Besides, his observation of the manners, customs, philosophies, religions and forms of government of foreign peoples has led to his observation of his culture. Placing the African and American cultures on an equal footing, African Son departs from Conrad's Heart of Darkness and from many other travelogues about Africa. In other words, the book shows that the visited countries and the traveler's country of origin, in this case the US, all embed the same ills inherent in all human societies. This stance thus blurs the border between the self and the other, thus deconstructing the center through the Derridan freeplay ${ }^{1}$ of the elements of a structure.

In the first sketch, what the reader retains is the Diops' willingness to welcome the American traveler who is given a place in 'the heart of the [Senegalese] family,' and the young Peace Corps volunteer's eagerness to be a part of this African family. During Iba's mourning, the narrator observes: 'I practiced the correct pronunciation of the Arabic words of condolence, and headed back to my place in front of my family's compound' (5). The possessive 'my' in 'my place' and 'my family' erases the racial and class barriers that may exist between the white foreigner and the natives. Acknowledging Derrida's mobility and permutability of the center and the margin, the American traveler is ready to reassess both his American culture and the Senegalese culture represented by the Diops. This reassessment is done through rhetorical questions:

Anyway, she [Maïmouna, Abdou's wife] talked easily to me despite the differences that separated us. Did it matter to her that I had spent four years in New York at college? What was New York-or higher education - to her? Could she have understood that my mother was

\footnotetext{
${ }^{1}$ Derrida observes that 'No doubt that by orienting and organizing the coherence of the system, the center of a structure permits the freeplay of its elements inside the total form. 'J. Natoli \& L. Hutcheon, p. 224. The freeplay of these elements decenter the center.
} 
an alcoholic, that growing up for me offered much less of the family togetherness than, despite their poverty, her family enjoyed? Could she have known that I was afraid of assuming responsibility for another person, having grown up in a culture that encourages independence but neither care nor compassion? (3)

These questions underscore the weaknesses and the strengths of the Western and African cultures. If the Diops' African traditional vision, which considers having a great number of children, despite the parents' meager financial means, a proof of wealth and manhood is questionable in the African modern set up, the American culture that encourages independence and not compassion is also bitterly criticized.

The narrator's comparison of his family that is financially self-sufficient but lacks togetherness to the Diops' family that is poor but epitomizes togetherness, showcases that Africa, the land of poverty, teaches the need for compassion and togetherness to the rich West that preaches self-reliance and independence, but fails to acknowledge the gross natural and social inequalities that may question the concepts of self-reliance and independence. Baïdy, the youngest child does not only epitomize the disparities between the West and Africa, but also the gulf that exists between the rich African rulers and their poor masses that are victimized by the latter's rapacity.

African Son also deconstructs the misrepresentation of the African landscape as an impenetrable jungle that transforms humans into beats. The second chapter 'Grass' celebrates the African savannah and its role in shaping Western homes. This landscape stands for calming home spaces and origin of the human feeling of home:

Socio-biologists talk about the 'savannah syndrome,' a sort of genetic blue printing that predisposes people to prefer landscapes that feature an ocean of short grasses interrupted by occasional islands of vertical trees. So, the thinking goes, people automatically associate a landscape of short grass and singular trees with identifiable and calming home spaces. So it may be that we atavistically trace our feelings of home and home spaces back to aboriginal African ancestors despite the varied terrains of our present lives. The savannah scape of seasonal grass and rugged, rare trees, according to the theory, imprinted on human psychology and, more important, planted inside the human genome. The savannah is thus the original and archetypal eden, despite claims of Jews or Christians. (6)

The African land is far from being the frightful jungle depicted in Conrad's book. In this sketch, the grass links the author to the Senegalese land and makes him feel part of this land. He is the land and the land becomes his, thus the feeling of home, in the author's opinion, originates from 'aboriginal African ancestors.' 
In this chapter, like in the previous one, the narrator compares the African landscape to his American rural spaces:

...Finally the rain came in horizontal sheets, pooling up and then disappearing into the sieve-like soil. In that sudden fierce storm I felt strangely vulnerable in that little collection of huts on that expanse of flat land surrounded by grassy bush and no sizable trees. Yet I also felt an ineffable closeness to that land, as if it had been a place I had known all my life. At that moment I was struck by the beauty of the village to which I felt a calming emotional connection. Maybe it was a sudden onset of the savannah syndrome, but this was not my first acquaintance with grass nor with quiet rural spaces. As a good Midwestern boy, I had grown up mowing - and hating - lawns, and I spent my first ten (and happy) years living on a dysfunctional farm in northern Ohio. No, my affection for the village in its isolated association with encompassing grass was real, and it was strong. It felt like home. (10)

This comparison gives some advantage to the African continent. Despite his acquaintance with grass on his American soil, the twenty-one year-old youth feels awe and love for the African soil, which endows him with a new worldview that enables him to liaise between his landscape in northern Ohio and the life giving grass of a northern Senegalese village. This thus paves the way for the new meaning that the American young man gives to home and the new feeling he has toward it.

Africa is not just a calming home space; it is a locale that bodes well for self discovery and spirituality, as depicted in 'Naming the Faith,' one of the best essays of the book. Like Charles Eugene de Foucauld who achieves self discovery among the Tuareg and Fulani nomads of the Sahara, Hemminger can understand the real meaning of faith in Saneinte, Moctar's village. If he teaches French to the materially destitute young Senegalese, the latter teaches him the real meaning of faith through his selflessness, asceticism and religious fervor, despite the hurdles and natural disasters that he and his village people have to face. Foucauld, Moctar and Hemminger come to the conclusion that it was necessary to live the life of the poor to understand what is most precious and most truly human about life' (11-12). This understanding results in the author's acknowledgement:

And I too have learned from an unlikely master-the young Senegalese Muslim with a bad eye, El Hadj Moctar Bousso. He taught me that wisdom starts with a commitment to a people and a place. I now know that such spiritual lessons are good for usbecause of, not despite, the privation. They help us to know and name our own faith. (19) 
Although the young American has university education and degrees, he learns from his African student. This is evidence of the effacement of the dichotomy between self and other. Moctar, the African student becomes his white teacher's instructor, thus making him acquire one of the main principles of African solidarity: 'no matter how bad things are, there is always someone for whom things are worse.' The author's remark, 'I couldn't help thinking how, in countries where capitalism motivates social activity, people with so much more give so much less' (15) targets his capitalist American society and modern African societies depicted in the first section of this paper.

In Chapter Seven, Marian marries Mutare, learns the language of the natives, and provides aid to the hungry children, thus proving that there is still hope for the African land. Marian and the metaphor of the shared meal in chapter Eight, 'Dining in Africa-A Parable,' exemplify the African traditional communal ethics, which the author considers the roots of genuine democracy:

The meal is also a demonstration of a tacit understanding among the villagers - that it is good to suppress one's individual needs for the well- being of the group. Squatting among friends and family members, the Senegalese villagers consciously curb their own appetites as they share the common food of human togetherness. (Hemminger 46)

Democracy based on sharing and togetherness is diametrically opposed to that which modern African rulers in general and Cameroonian politicians in particular, construct on wealth and alterity in Chapter Nine, 'Out of Country'. These rulers rather beggar their country and underpin the stereotypical images assigned to Africa. To slough off these stereotypes, these administrators should rid themselves of their colonialist ideology and perception of Africa. The African native's interaction with his/her continent should influence the Western traveler's perception of Africa and his/her interaction with the latter. This interaction should not have any taint of exploitation nor humiliation; it must be similar to the encounter between Magellan and Hemminger in Chapter fourteen, 'Interaction'. The American professor visits the Cameroonian native in his slum without any complex of superiority; he offers Magellan some money for the education of the latter's first son.

However, Magellan does not assume the position of a beggar; despite his appalling living conditions, he works hard to eke out the necessities of life. $\mathrm{He}$ welcomes the American visitor and manages to offer him bottles of soft drinks, a healthy bunch of bananas and a bottle of scotch. This interaction portrays another image of Africa; the latter is not the perennial mendicant; it has something to offer: its idea of progress that is not just gauged in terms of material progress, but also in terms of compassion and solidarity. 'African Son', the title of the book thus connotes belonging, being and feeling part of Africa. The African native and the Western traveler who shed their colonialist and imperialist mentality when approaching Africa become the sons or daughters of this land. 
The postcolonial reading of Hemminger's African Son, has led to the following findings:

- Africa, far from being the dark and dehumanizing continent, is an epitome of solidarity and compassion, as its traditional communal ethics teaches sharing and togetherness, valuable components of democracy.

- In this continent's traditional set up, progress is not just assessed in terms of material wealth, but more through the people's ability to implement communal ethics. In this respect, Africa has a lot to contribute to the global community.

- The African native, who lives in his/her continent with a colonialist mindset, ends up becoming a narrow-minded traveler in his/her own continent.

- Travel writing should abandon the reductive binary self/other that characterizes colonialist travelogues to adopt an inclusive move that takes cognizance of the strengths and weaknesses inherent in all human communities. This move will enable this genre of literature to adjust to the present global context that paradoxically preaches the erasure of political, economic, geographical and cultural boundaries, while it witnesses the rise of racial essentialism.

\section{Conclusion}

This article has shown that colonialist travel writing misrepresents the other, especially the African other. Like Krumholz, Hemminger posits that one of the objectives of travel literature today should be the reconciliation of the self and the other, the west and the orient, the north and the south. Through his comparative approach, the author has highlighted, without any bias, the weaknesses and strengths of the African culture, as well as those of his American culture. He therefore clearly purports that Africa, the nature continent, associated with innocence, solidarity and compassion may lose all these attributes if its political, economic and cultural decision makers adopt a colonialist mindset, which favors the misrepresentation of this land as the dark and backward continent.

\section{References}

Achebe, Chinua. (1988) [1977] 'An Image of Africa: Racism in Conrad's 'Heart of Darkness." In Robert Kimbrough (ed.), Heart of Darkness, An Authoritative Text, Background and Sources Criticism, $3^{\text {rd }}$ ed., 251-261. London: W. W Norton and Co.

Bradshaw, R. (2012). "Blurb" African Son. Lanham: University Press of America. 
Chew, S.\& D. Richards eds. (2010). A Concise Companion to Postcolonial Literature. Malden, MA: Wiley- Blackwell.

Conrad, J. (2003) [1899]. Heart of Darkness and Other Selected Fiction. New York: Barnes \& Noble Classics.

Derrida, J. (1993) [1970] 'Structure, Sign and Play in the Discourse of the Human Sciences.' In J. Natoli \& L. Hutcheon (eds.), A Postmodern Reader, 223- 242. New York: State University of New York Press.

Hemminger, W. J. (2012). African Son. Lanham: University Press of America.

Hulme, P. \& T. Youngs. (2002). the Cambridge Companion to Travel Writing. Cambridge: Cambridge University Press.

Inge, M. T. (1969). Agrarianism in American literature. New York: Odyssey Press.

Innes, C.L. (2010). 'The Politics of Rewriting.' In S. Chew \& D. Richards (eds.), A Concise Companion to Postcolonial Literature, 56-77. Malden, MA: Wiley- Blackwell.

Krumholz, L.J. (Spring 2002). 'Reading and Insight in Toni Morrison's Paradise.' African American Review, 36(1):21-34.

McKay, C. (1998) [1921]. 'Africa.' In Nina Baym et al. (eds.), The Norton Anthology of American Literature, $5^{\text {th }}$ ed. Vol. 2, 1408. New York \& London: W.W. Norton \& Co.

Offord, D. (2005). Journeys to a Graveyard: Perceptions of Europe in Classical Russian Travel Writing. Dordrecht: Springer.

Oh, Eunyoung. (2007). D.H. Lawrence's Border Crossing: Colonialism in His Travel Writings and "Leadership" Novels. New York \& London: Routledge.

Said, E. W. (2003) [1978] Orientalism. London: Penguin Classics.

Youngs, T. (2002). 'Africa/ The Congo: the Politics of darkness.' In P. Hulme \& T. Youngs (eds.), The Cambridge Companion to Travel Writing, 156173. Cambridge: Cambridge University Press.

Sympson, J. Online Comment. 26 Mar. 2013. Available at http://www.amazon. fr/African-Son-William-J-Hemminger/dp/0761858431[7 June 2014] 